\title{
TUNGSTEN NEUTRON ELASTIC- AND INELASTIC-SCATTERING CROSS SECTIONS FROM 4.34 TO $8.56 \mathrm{MeV}$
}

\author{
W. E. Kinney \\ F. G. Perey
}


BLANK PAGE 


\section{Printed in the United States of America. Available from}

National Technical information Service

U.S. Department of Come.urce

5285 Port Royal Raed, Springfield. Virginia 22151

Price- Printed Copy SA.00; Microfiche 50.95

This report was prepared as an account of work sponsored by the United States Governnent. Neiffer the United States nor the United Stentes Atomic Eneror Commission. nor any of their emolovees, nor any of their contractors. subcontrseztors, or their erployes, makes any norrenty. express or implied, or assumes any legel liebility or essponsibility for the sccurecy, completeness of usefulness of eny information, eppenretus. product or process disclosed. or represents that its use nould not infringe privately ownes rights. 


$$
\begin{gathered}
\text { ORNL-4803 } \\
\text { UC-34 - Physics }
\end{gathered}
$$

Contract No. W-7405-eng-26

Neutron Physics Division

TUNGSTEN NIUTRON ELASTIC- AND INELASTTC-SCATTERING CP.OSS SECTIONS FROM 4.34 TO $8.56 \mathrm{MeV}$

W. E. Kinriey and F. G. Perey

\section{MAY 1973}

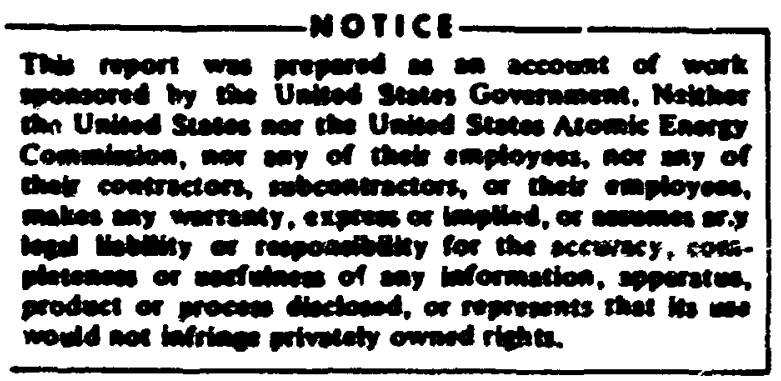

OAK RIDGE NATIONAL LABORATCRY

Oak Ridge, Tennessee 37830 operated by

UNION CARBIDE CORPORATION for the

U.S. ATOMIC ENERGY COMMISSION

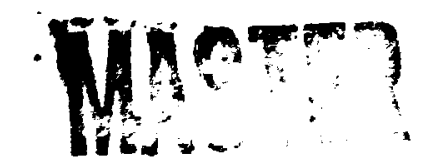


Page No.

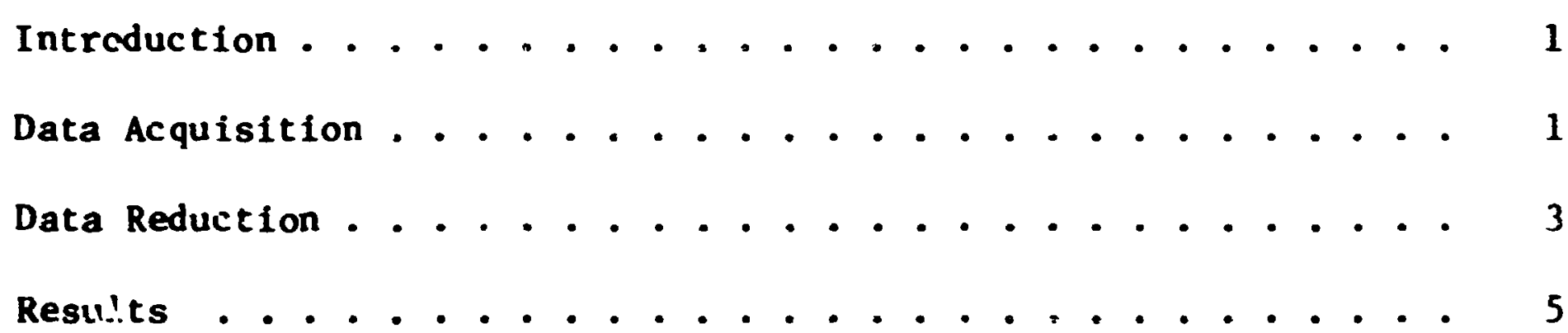

Elastic Scattering and Inelastic Scattering to Low-Lying

Levels.................... 5

Inelastic scattering to Level >0.123 MeV . . . . . . . 11

Conciusions . . . . . . . . . . . . . . . . . 18

Acknowledgements . . . . . . . . . . . . . . . . 19

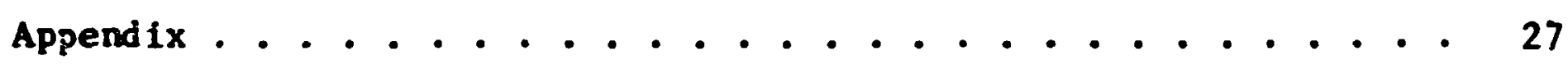


TUNGSTEN NEUTRON ELASTIC- AND INELASTIC-SCATTERINC

CROSS SECTIONS FROM 4.34 TO $8.56 \mathrm{MeV}$

W. E. Kinney and F. G. Perey

\begin{abstract}
Measurer natural tungsten neutron elastic- and inelastic-scattering cross sections are presented and shown to be in good agreement with the results of others. An evaporation model of inelastic scattering was found to be applicable with nuclear temperatures in agreement with previous results but with total inelastic cross sections larger by as much as $20 \%$ than measured nonelastic cross sections. ENDF/B W (Mat 1060-63) elastic angular distributions agree with our data at angles less than $50^{\circ}$ but do not at larger angles. The ENDF/B nuclear temperatuces are 10-15\% lower than experimental temperatures.
\end{abstract}

\title{
INTRODUCTION
}

We present neutron elastic- and inelastic-scattering cross sections for natural tungsten at $4.34,4.92,6.44,7.54$ and $8.56 \mathrm{MeV}$. To assist in the evaluation of our data, we briefly discuss our data acquisition and reduction techniques.

For the purposes of discussion, we present our data in graphical form where we compare with the resuits of others and wi:h ENDF/B (Evaluated Neutron Data File B). Tables of our numerical vajues of the cross section are given in the appendix.

\section{DATA ACQUISITION}

The data were obtained with conventional time-of-fligh: techniques. Pulsed (2MHz), bunched ( $\sim 1$ nsec full width at half maximim, FWhM) deuterons accelerated by the ORNL Van ie Graaff's interacted with deuterium in a gas cell to prodiuce neutrons by the $D(d, n)^{3}$ He reaction. The gas cells, of length 1 and $2 \mathrm{~cm}$, were operated at pressures of approximately 1.5 atm and gave neutron eneriy resolutions of the order of $\pm 60 \mathrm{keV}$. 
The neutrons were scattered from a solid right circular cylindrical sample of natural tungsten, $0.953 \mathrm{~cm}$ diameter and $2.56 \mathrm{~cm} \mathrm{high,} \mathrm{placed}$ approximately $10 \mathrm{~cm}$ fror. the gas cells when the detector angles were greater than $25^{\circ}$. For smaller detector angles the cell-to-sample distance had to be increased to as much as $30 \mathrm{~cm}$ in order to shield the detector from neutrons coming directly from the gas cells.

The scattered neutrons were detected by $12.5-\mathrm{cm}-\mathrm{diam} \mathrm{NE}-213$ 1iquid scintillators optically coupled to XP-1040 photomultipliers. The scintillators were normally $2.5 \mathrm{~cm}$ thick. Deta were taken with three detectors simultaneously. Flight paths were approximately $5 \mathrm{~m}$ with the detector angles ranging from 15 to $140^{\circ}$. The gas-cell neutron production was monitored by a time-of-flight system which used a $5-\mathrm{cm}-\mathrm{diam}$ by $2.5-\mathrm{cm}-$ thick NE-213 scintillator viewed by a 58-AVP photomultiplier placed about $4 \mathrm{~m}$ from the cell at an angle of $55^{\circ}$ with the incident deuteron beam.

For each event a PDP-7 computer was given the flight time of a detected recoil procon event with reference to a beam pulse signal, the pulse height of the recoil proton event, and identification of the detector. The electronic equipment for supplying this information to the computer consisted, for the most parr, of standard commercial components. The electronic bias, determined by deterioration of gamma-neutron discrimination, was set at approximately $700-\mathrm{keV}$ neutron energy.

The detector efficiencies were measured by $(n, p)$ scattering from a thin (6-mm-diam) polyethylene sample and by detecting soirce $D(d, n)^{3} \mathrm{He}$ neutrons. Both interactions gave resules which agreed with each other and which ylelded efficiency vs energy curves that compared well with calculations. 1 
DATA REDUCTION

Central to the data reduction process was the use of a light pen with the PDP-7 computer oscilloscope display programs to extract peak areas from spectra. The light pen made a comparatively easy job of estimating errors in the cross section caused by extrene but possible peak shapes.

The reduction process started by normaíizing a sampie-out to a sampiein time-of-flight spectrum by the ratio of their monitor neutron peak areas, subtracting the sample-out spectrum, and transfcrming the difference spectrum into a spectrum of center-of-mass cross section vs excitation energy. This transformation allowed ready comparison of spectra taken at different angles and incident neutron energies by removing kinematic effects. It also made all sirglet peaks have approximately the same shape and width regardless of excitation energy (in a time-of-flight spec:rim, singlet peaks change shape drastically with flight time). A spectrum of the variance based on the counting statistics of the initial data was also coniputed.

The transformed spectra were read into the PDP-7 computer and the peak stripping was done with the aid of the light pen. A peak was stripped by drawing a background beneath 1t, subtracting the backgrrand, and cal.culating the area, centroid, and FWHM of the difference. The variance spectrum was used to compute a crinting statistics variance corresponding to the stripped peak. Peak stripfing errors due to uncertainties in the residual background under the peaks or to the talls of imperfectly resolved nearby peaks could be included with the other errors by stripping the peaks several times corresponding to high, low, and best estimates of this background. Although somewhat subjective, the low and high estimates of the cross $3 e c t$ ions were 
identified with $95 \%$ confidence limits; these, together with the best estimate, defined upper and lower errors due to stripping. When a spectrum was completely stripped, the output information was written on magnetic tape for additional processing by a large computer.

Inelastic cross sections were sufficiently isotropic so that finite samplé corrections could be made at each angle independently of results at other angles. Correction of the elastic cross section, however, had to await the reduction of the entire angular distribution before the finite sample effects could be treated. The corrections were performed according to semianalytic recipes whose constants were obtained from fits to Monte Carlo results. ${ }^{2}$ The corrections are largest in the first minimum of the elastic dif first minimum at $4.34 \mathrm{MeV}$ but decreasing to $\sim 15 \%$ at $8.56 \mathrm{MeV}$.

The final error analysis included uncertainties in the geometrical parameters (scatterer size, gas cell to scatterer distance, flight paths, etc.) and uncertainties in the finite sample corrections.

The ground state was fitted by least squares to a Legendre series:

$$
\sigma(\mu=\cos \theta)=\sum_{\ell=0} \frac{2 \ell+1}{2} a_{\ell} P_{\ell}(\mu)
$$

the points teing weighted by the inverse of their variances. In order to prevent the fit from giving totally unrealistic values outside the angular range of our measurements, we resorted to the inelegant but workable process of adding three points equally spaced in angle between the largest angle of measuremert and $175^{\circ}$. The differential cross sections at the added points were chosen to approximate the diffraction pattern at large angles, but were assigned $50 \%$ errors. 
RESULTS

Elastic Scattering and Inelastic Scattering to Low-Lying Levels

Differential cross sections for predominantly elastic scattering are shown in Figure 1 along with the Legendre fits we used to integrate the distributions over angle. Mr resolution was not sufficientiy good to separate inelastic scattering to levels of energy up to $0.123 \mathrm{MeV}$ from elastic scattering. On the basis of the counts in the time-of-flight spectra just below the 'elastic-scattering' peak, assuming a similar contribution for inelastic scattering to levels not resolved from the 'elastic-scattering' peak, we estimate that the unresolved inelastic levels contribute less than $6 \%$ to the 'elastic-scattering' data.

Our differential cross sections are compared with those of others in Figure 2. The ENDF/B-III ${ }^{+}$elastic differential cross sections for Mat 1060 through $1063\left({ }^{182} \mathrm{~W},{ }^{183} \mathrm{~W},{ }^{184} \mathrm{~W}\right.$, and ${ }^{186} \mathrm{~W}$, respectively) are also shown. These were obtained by combining the information for the isotopes ${ }^{182} \mathrm{~W},{ }^{183} \mathrm{~W}$, 184 and ${ }^{185} \mathrm{~W}$, MAT 1060 through 1063.

The ENDF/B Legendre coefficients for natural tungsten were determined by

where

$$
f_{\ell}=\frac{\sum_{i=1}^{4} a_{\ell}^{i} p_{i} \sigma_{s i}}{\sum_{i=1}^{4} p_{i} \sigma_{s i}}
$$

$\mathrm{f}_{\ell}=$ the $\ell$ th Legendre coefficient for natural tungsten,

$a_{\ell}^{i}=$ the $\ell$ th Legendre coefficient for the $i$ th isotope,

$\mathrm{p}_{1}=$ the natural isotopic abundance for the ith isotope,

$\sigma_{s i}=$ the ENDF/B-III angle-integrated elastic-scattering cross section for the ith isotope.

+Tungsten is currently being reevaluated by P. F. Rose at Atomics International. 


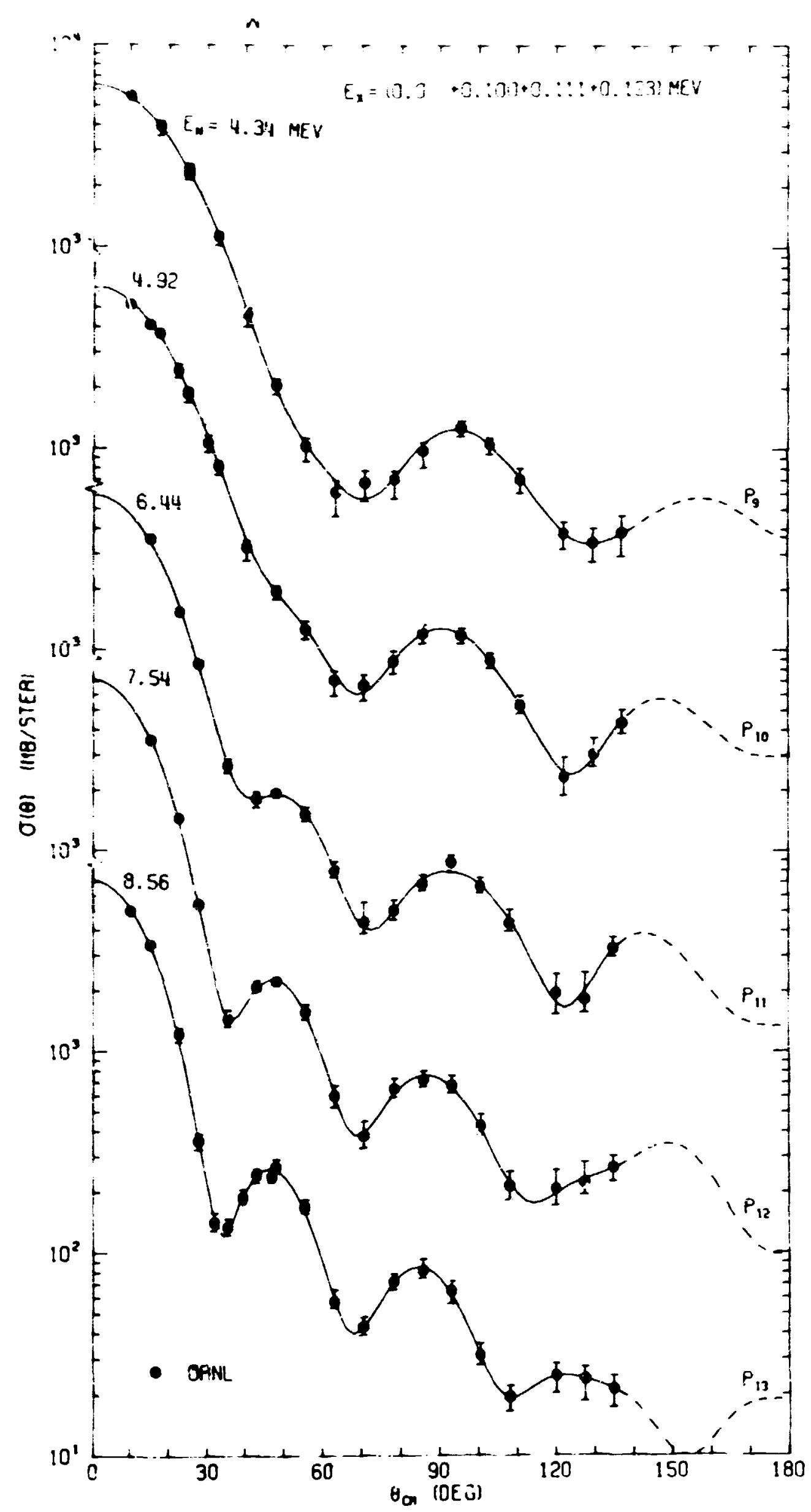

Fig. 1. Our neutron differential cross sections for natural tungsten for elastic scattering and inelastic scattering to levels $\leq 0.123 \mathrm{MeV}$. The curves are Legendre fits to the data. 

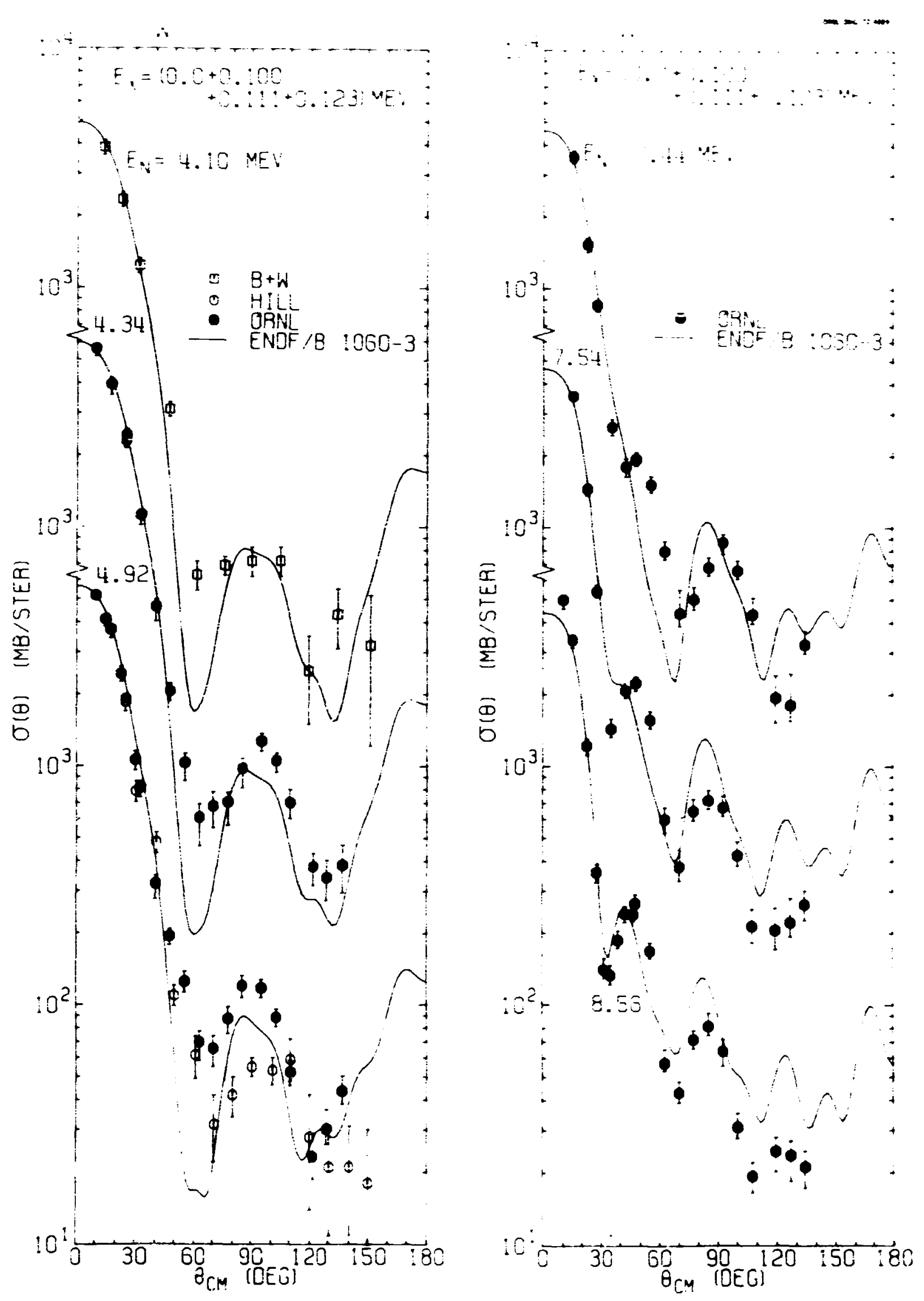

Fig. 2. Our neutron differential cross sections for natural tungsten for elastic scattering and inelastic scattering to levels $<0.123 \mathrm{MeV}$ together with the data of Beyster and Walt (B\&W) and Hill. The curves are ENDF/B elastic differential cross sections for the tungster isotopes (Mat 1060 through Mat 1063) combined with natural isotopic abundances and normalized to the experimental integrals. 
The ENDF/B angular distributions were normalized to experinental integrated elastic-scattering cross sections.

Our results appear to be consistent with those of Beyster and Walt $(B+W)^{3}$ at $4.10 \pm 0.04 \mathrm{MeV}$. At angles less than $60^{\circ}$, our data agree with that of $\mathrm{Hill}^{3}$ who measured at $5.0 \pm 0.1 \mathrm{MeV}$; but our data are about a factor of iwo higher in the second maximum. The ENDF/B-III angular distributions agree within errors at angles less than $50^{\circ}$, except possibly at $8.56 \mathrm{MeV}$. Ar angles greater than $60^{\circ}$, however, ENDF/B-III angular distributions rarely agree with the data within experimental errors and also show structure not evident ir. the data.

An interesting comparison of our elastic differential cross sections for natural tungsten $(Z=74, A=193.6)$ is made with similar data of Holmqvist and wiedling ${ }^{6}$ for natural tantalum $(Z=73, A=181)$ in Figure 3 . The curves are our Legendre fits to our data and Holmqvist's and Wiedling's Legendre fits to their data. It would be expected that neighboring nuclei in this mass region should have very simflar differential elastic-scattering cross sections and, although our data integrate to values approximately $20 \%$ higher than do the data of Holmqvist and Wledling, the shapes are very much the same. The evolution of what at $8.56 \mathrm{MeV}$ is the first minimum is most striking while the occurrence of the other minima at smaller angles with increasing energy is also evident.

Our angle-integrated differential cross sections for elastic scattering and inelastic scattering to levels $\leq 0.123 \mathrm{MeV}$ are compared with the elastic cross section of ENDF/B in Figure 4. The evaluation lies within our errors except at $6.44 \mathrm{MeV}$ where it $1 \mathrm{~s} 12 \%$ higher. 


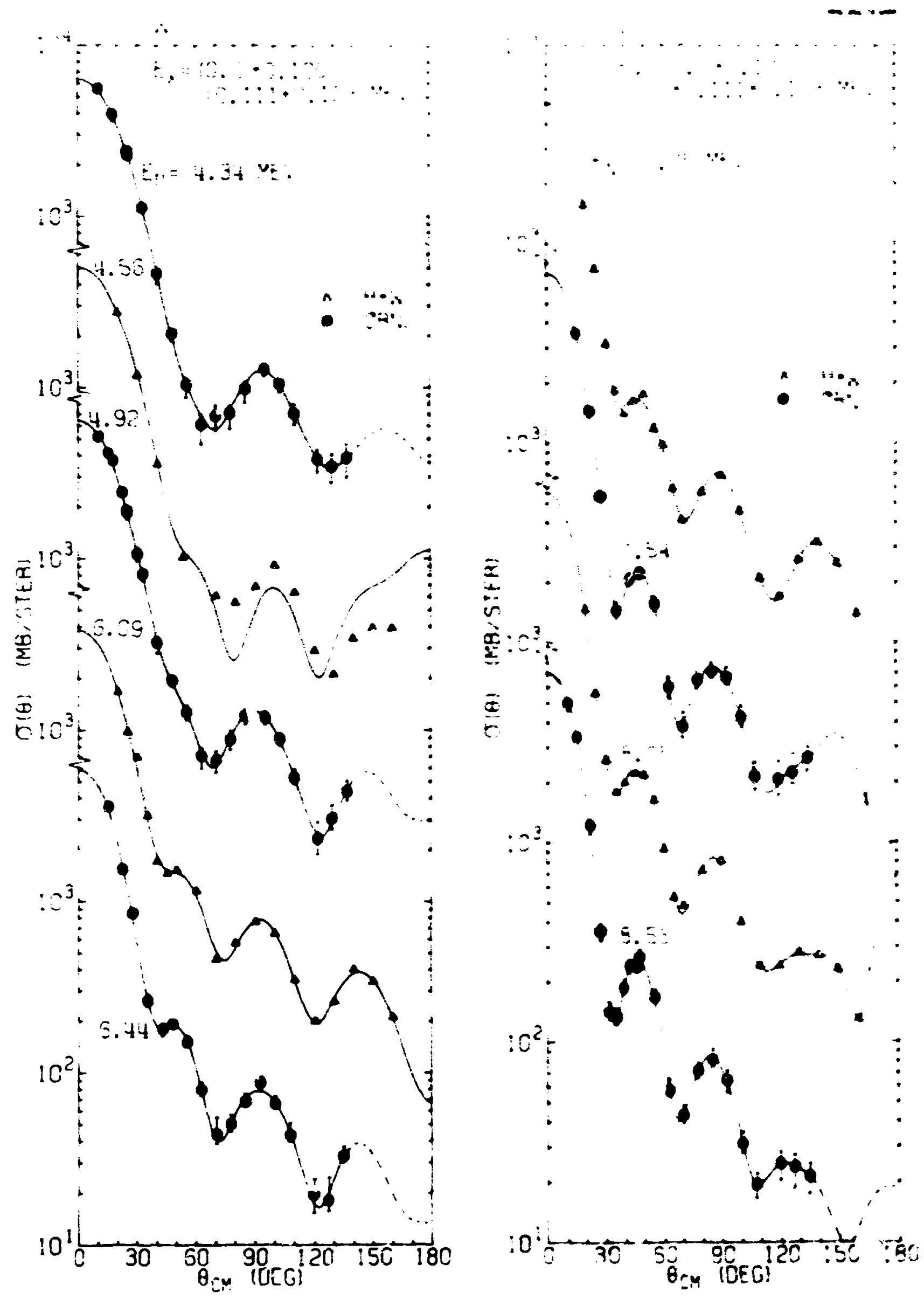

Fig. 3. Our neutron differential cross sections for natural tungsten for elastic scattering and Inelastic scattering to levels $: 0.123 \mathrm{MeV}$ compared with neutron differential cross sections of Holaquist and Wiedling (H\&W) for natural tantalum. 

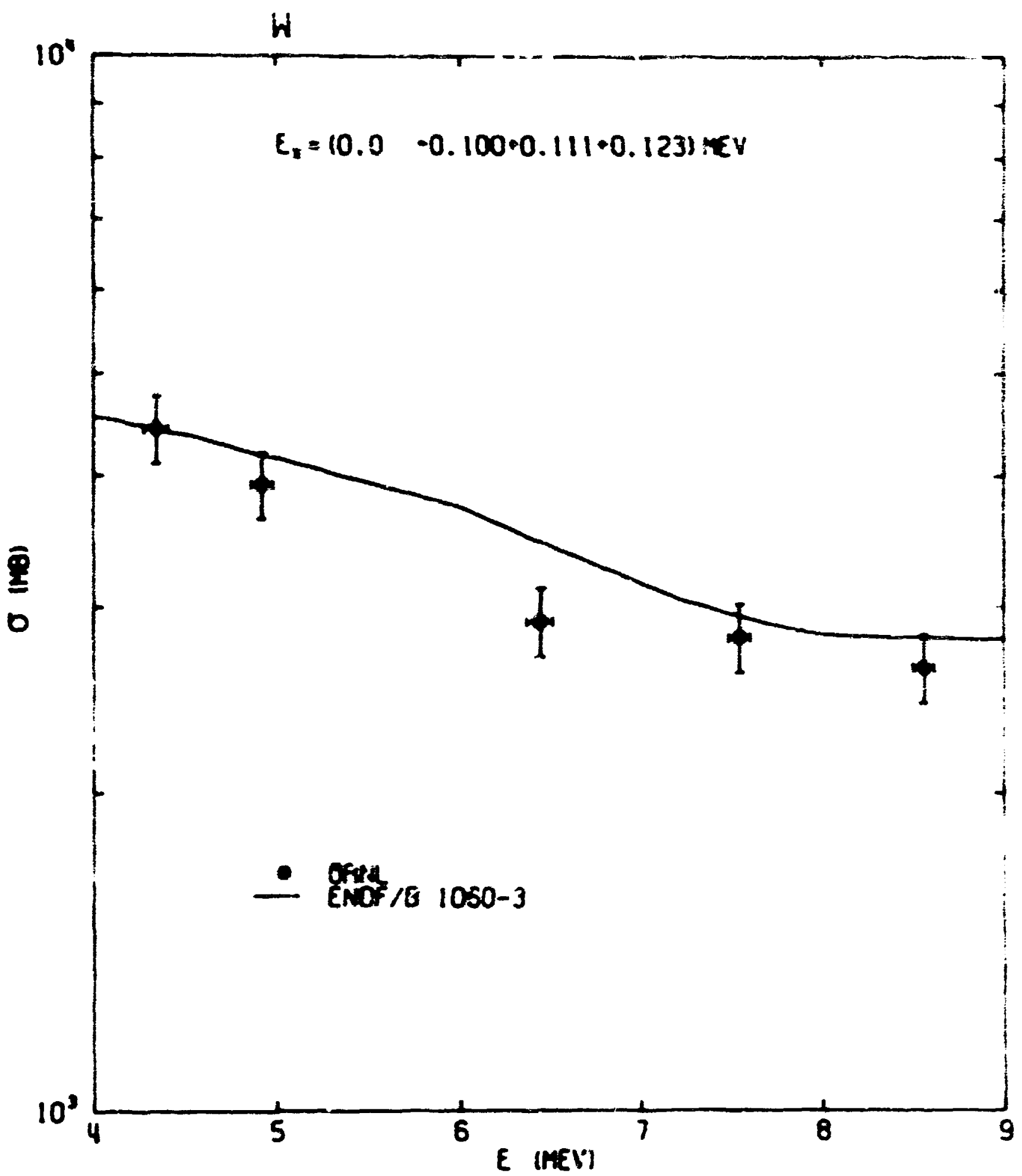

F18. 4. Our angle-integrated differentiwl cross sections for natural tungsten for elastic ecatering and inelastic scattering to levels $\leq 0.123$ MeV compared with ENDF/8 Mat 1060-63. 
Inelastic Scattering to Levels $>0.123 \mathrm{MeV}$

The relativeiy high energy level density of the turgsten isotopes, the presence of four isotopes in ratural tungsten with abundances from 14 to $30 \%$, and our resolution of - $\$ 60 \mathrm{keV}$ combined to prevent our resolving inelastic scattering into cross sections for scattering to particular levels ot small groupss of few levels. Rather, fruelastic scattering appeared as scattering to a contiruum of levels as shown in F'gure 5 where our angleaveraged double differential cross sections for inelastic scattering are plotted versus excitation energy for our five incident neutron energies.

As the incident neutron energy increases the number of levels open for deexcltation of the compound nucleus formed increases, decreasing the probability of inelastic scattering to a particular level. In fact, scatering to the lower lying levels in the tungsten isotopes becomes so small a: the higher incident neutron energies sc as to tecome of the order of magnitude of the background. Rather than quotz very large, and possibly ma:aningless, errors for the inelastic-scattering cross sections to these low-1ying levels, we only report inelastic-scattering cross sections to the continuum at increasingly higher excitation energies as the incident neutron energy increases. An evaporation model has been applied by others to tungsten continuum inelastic scattering to obtain nuclear temperatures. 7,8

In this model

$$
\sigma\left(E, E^{\prime}\right)=K E^{\prime} e^{-E^{\prime} / T}
$$




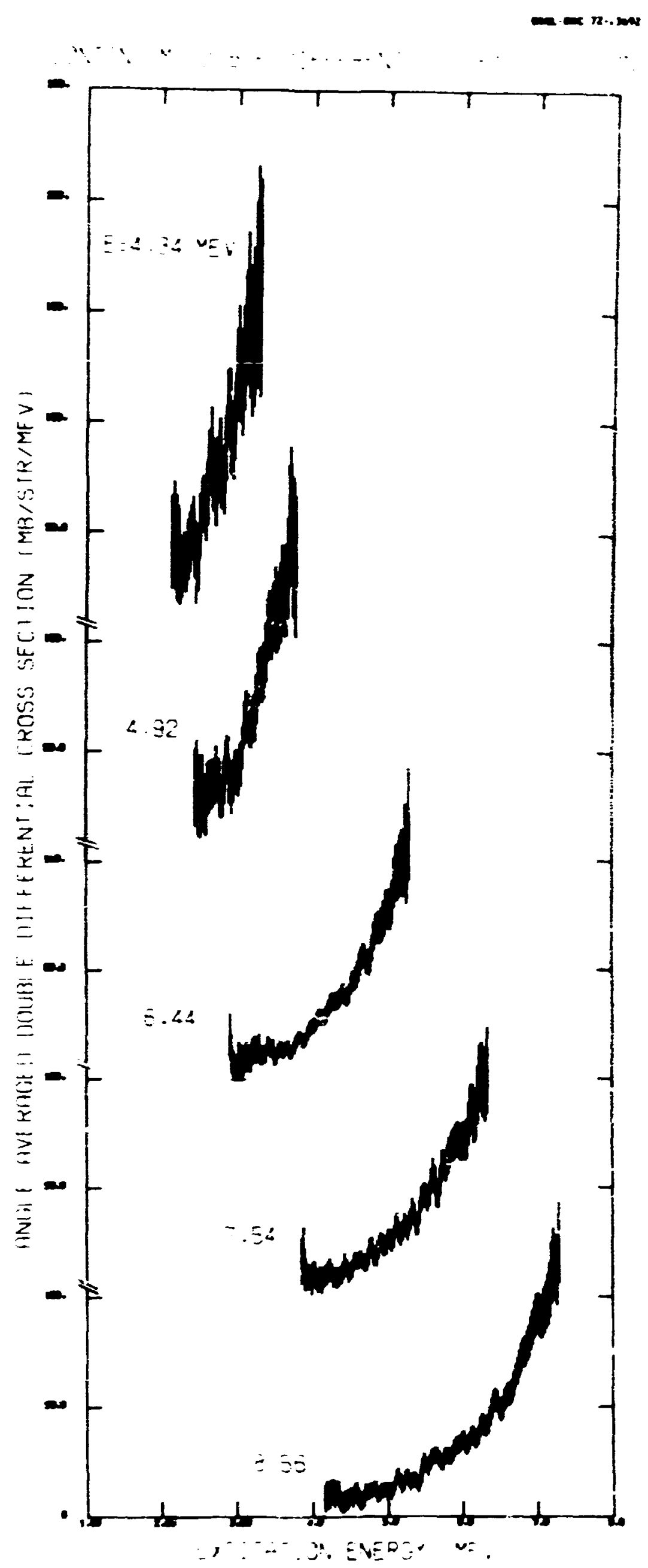

Fig. 5. Our angle-averaged doubif. differential cross sections for inelastic scattering to the continuum. 
where

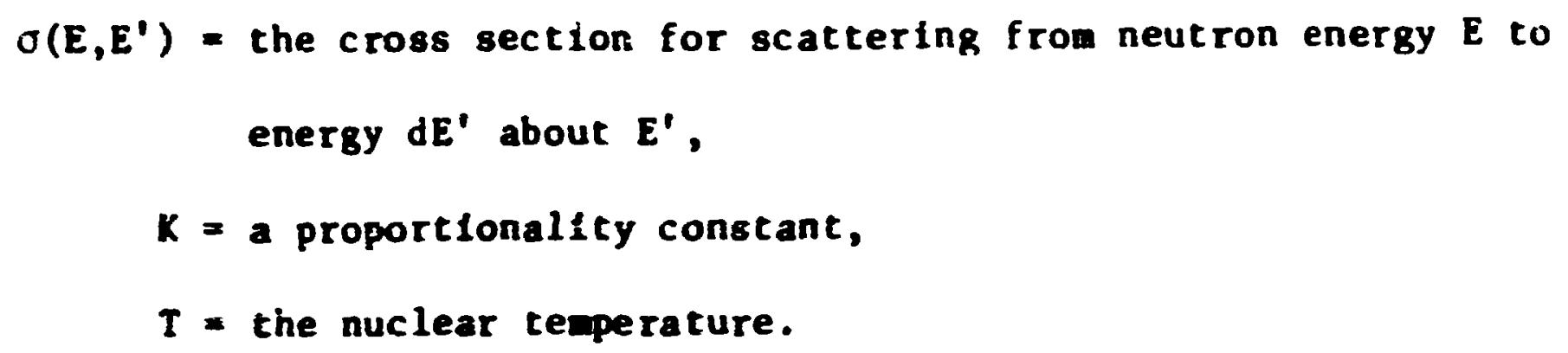

Plgure 6 shows plots of $\sigma\left(E, E^{\prime}\right) / E^{\prime}$ versus $E^{\prime}$ with least squares fits to the data. In the fitting only data with $E^{\prime}<2$ MeV were used for $E=$ 4.34 and $4.92 \mathrm{MeV} ; E^{\prime}<2.5 \mathrm{MeV}$ for $E=6.44 \mathrm{MeV}: E^{\prime}<3 \mathrm{KeV}$ for $\mathrm{E}=7.54$ and $8.56 \mathrm{KeV}$. The temperatures and their least squr, errors are indicated.

The nuclear temperatures teduced from our data are compared with those from other investigations ${ }^{7,8}$ in Figure 7 . The dotted line is a least squares fit to all the experimental points giving a dependence of temperature on incident neutron energy of

$$
T=0.223+0.055
$$

where

$\mathrm{T}=$ the temperaturz in $\mathrm{MeV}$,

$E$ = the ini:ident energy in liev.

The ENLF/B temperatures are given by the solid line and are seen to be 10-15\% lower than ise fit to experimental values.

The evayoration specirum, Eq. (2), may be integrated to give a to:al inelastic-scatcering cro:3s section

$$
\sigma_{\text {in }}=\iint c\left(E, E^{\prime}\right) d E^{\prime} d \Omega \because 4 \pi R T^{2}
$$

assuming an fsotropic angular distribution. The constants $K$ and $T$ were obtained from the least square fits show on Figure 6. The error on the 


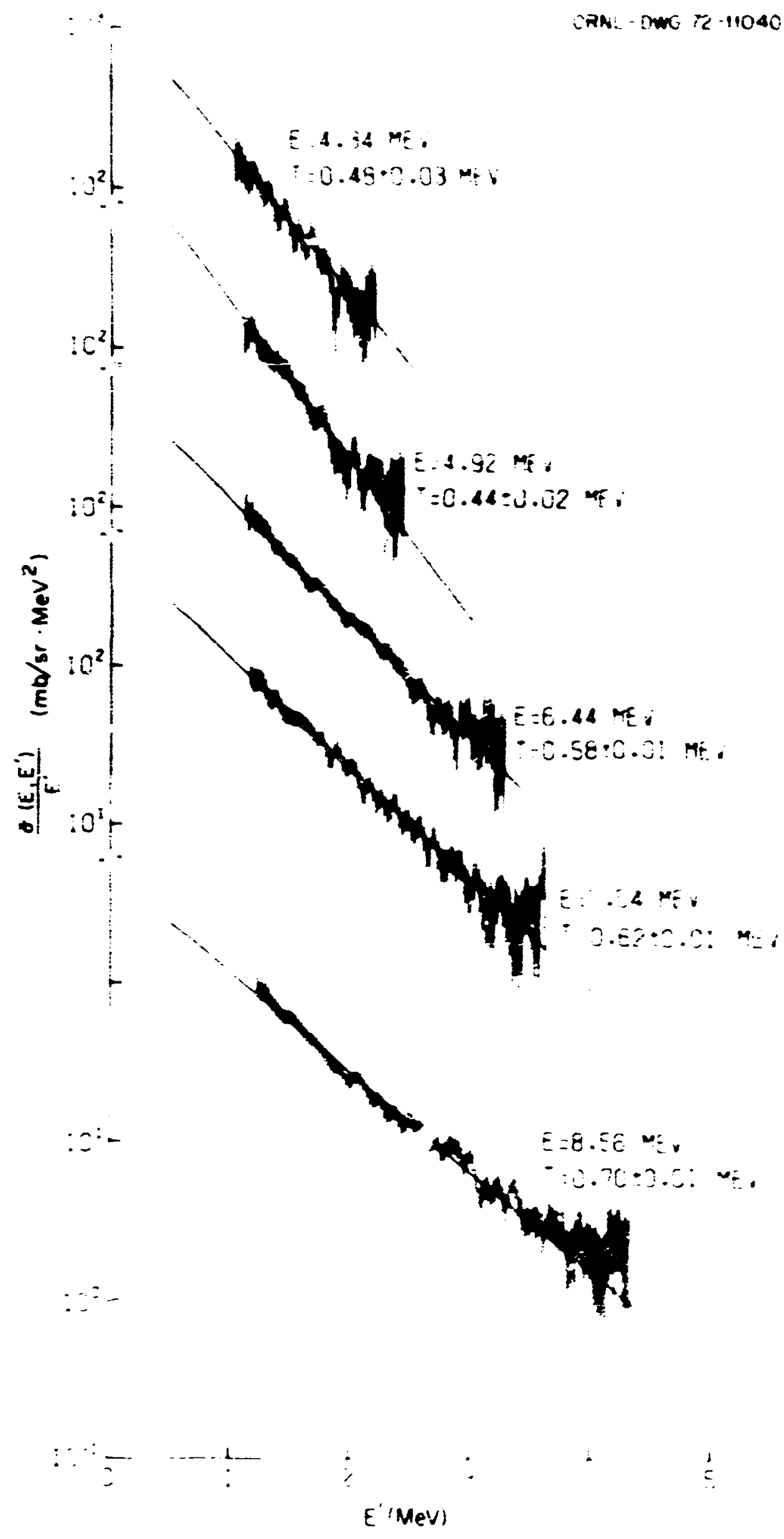

Fig. 6. Natural tungsten average neutron differential cross sections for scattering from energy $E$ t $=$ scattered energy $d E^{\prime}$ about $E^{\prime}$ divided by $E^{\prime}$ versus $E^{\prime}$. The straight lines are lenst souares fits to the data. $T$, the reciprocal of the plot of the lest fit line to the data, is the nuclear temperature characterizing each spectrum. 


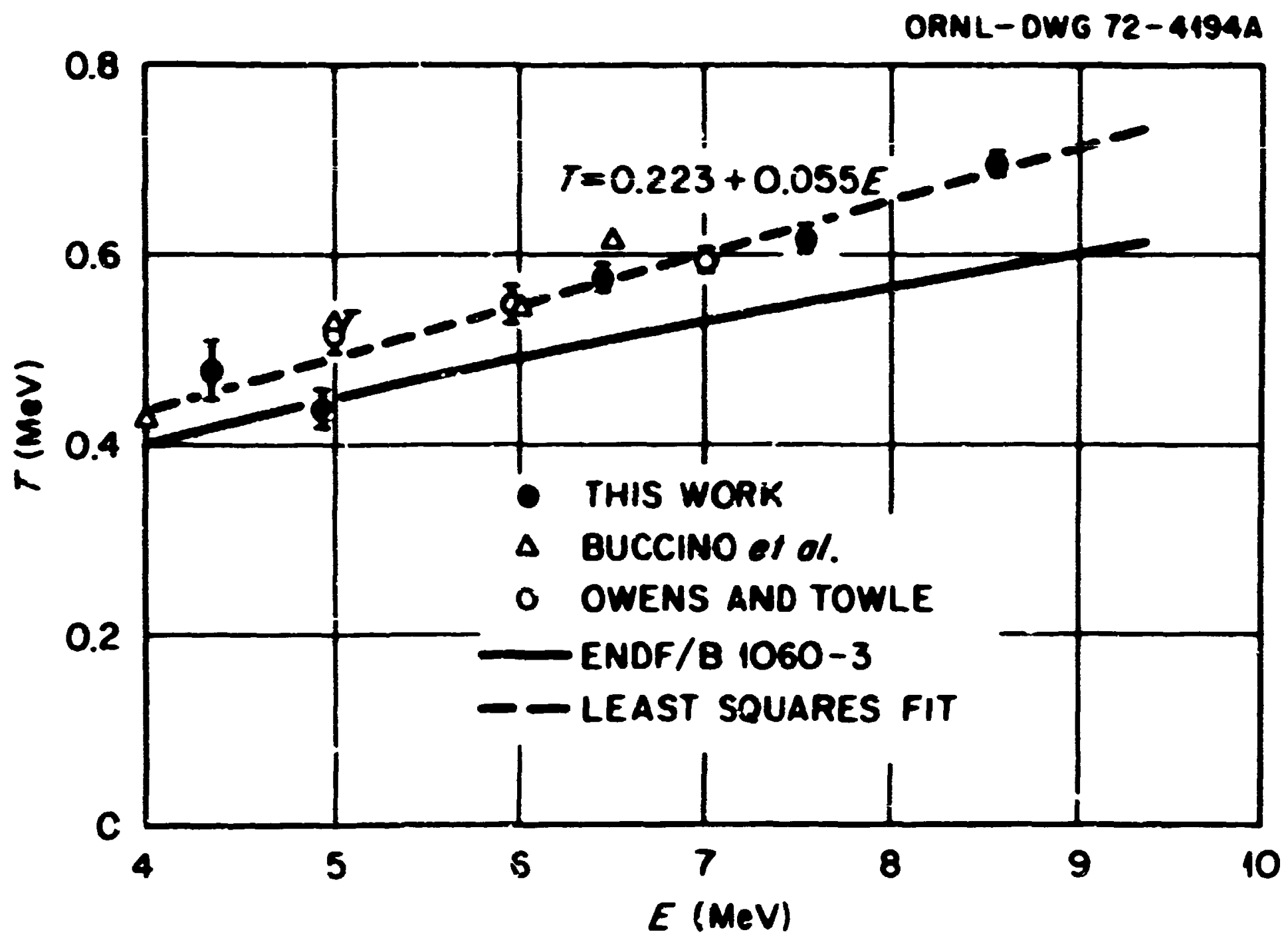

F18. 7. Our nuclear temperatures, $T$, for natural tungsten versus incident energy $E$ compared with results of others. The dotted line is a least squares fit to all the experimentaj data. The solid line, lying 10-15\% below the dotted, is the ElDF/B temperature vartation with energy. 
total inelastic scattering cross section computed using Eq. (3) is larger than the one derived only from the errors on $K$ and $T$, obtained from the fits of Figure 6 , since one is assuming that the unobserved part of the spectrum at low and high energies obey the same evaporation law. At the lower incident neutron energies of 4.34 and $4.92 \mathrm{MeV}$ the use of Eq. (3) is very unsatisfactory since the largest contribution to the integrated cross section would come from the unmeasured energy region of the spectrum. At these two low energies we belleve that the inelastic spectra can only be used to obtain an estimate on the temperature $T$, to characterize the measured part of the spectrum and should not be used to derive a meaningful total Inelastic cross section.

Table I lists the values we obtain from our data using Eq. (3) at $6.44,7.55$ and $8.56 \mathrm{HeV}$. The errors shown only include the contributions due to the uncertainties on $K$ and $T$ from the least squares $f$ it to the measured spectra. For comparison we also show the values of the nonelastic cross sections obtained by subtracting our total elastic-scattering cross sections from total cross sections, as well as nonelastic cross sections from Ref. 10. The results of Owens and Towle ${ }^{8}$ for total inelastic scattering and the values ENDF/B 1060 for nonelastic scattering are also inc ${ }^{1}$ uded. At the neutron energies given in Table $I$, the nonelastic-sc-ttering cross sections are only the sum of the inelastic-scattering and capture cross sections. Since the capture cross sections are relativley small in this energy region, a few millibarns, the nonelastic cross sections should be apfroximately equal to the inelastic cross sections. Table I shows a systematic discrepancy between nonelastic and inelastic cross sections. All of the data given for inelasticscattering cross sections in this table were obtained by using Eq. (3). 
Table I. A Comparison of Tungsten Total Inelastic and Nonelastic Cross Seclions. All Cross Sections are Given in Barns.

\begin{tabular}{llllll}
\hline E,MeV & $\sigma_{\text {non }}^{\mathrm{a}}$ & $\sigma_{\text {non }}^{\mathrm{b}}$ & $\begin{array}{c}\text { Total } \\
\text { Inelastic }\end{array}$ & $\sigma_{\mathrm{T}}^{-\sigma_{\mathrm{S}}}$ & $\sigma_{\mathrm{T}}^{\mathrm{c}}$ \\
\hline 5.00 & $2.6 \pm 0.3$ & 2.53 & $2.94 \pm 0.15^{\mathrm{d}}$ & & \\
6.00 & $2.5 \pm 0.3$ & 2.34 & $2.89 \pm 0.13^{\mathrm{d}}$ & & \\
6.44 & $2.5 \pm 0.3$ & 2.28 & $2.6 \pm 0.3$ & $2.5 \pm 0.2$ & $5.40 \pm 0.1$ \\
7.00 & $2.5 \pm 0.3$ & 2.32 & $2.87 \pm 0.17^{\mathrm{d}}$ & & \\
7.54 & $2.5 \pm 0.3$ & 2.32 & $2.7 \pm 0.3$ & $2.3 \pm 0.2$ & $5.13 \pm 0.1$ \\
8.56 & $2.5 \pm 0.3$ & 2.29 & $3.0 \pm 0.3$ & $2.4 \pm 0.2$ & $5.08 \pm 0.1$ \\
\hline
\end{tabular}

$a_{\text {Ref. } 10 \text { (BNL-325) }}$

${ }_{\text {ENDF/ B } 1060}$

c $_{\text {Ref. }}$ (LASL evaluation)

$d_{\text {Ref. }} 8$ (direct measurements) 
For the data of twens and Towle and our $8.56 \mathrm{MeV}$ results, too-large values of the Inelastic cruss jections are obtained from the use of Eq. (3). Wt have not investigatic in detail this problem. It could be that the low-energy part of the inelastic spectrum, which we do not obserse, has fewer neutions than predicted by the evaporation law based on the temperatur. T determined at higher energies. Or more likely, the error estimate which we obtain on the integrals using Fin. (3) do not properly reflect the uncertainties in the data. Further experiments, with particular attention given to hackground reduction and determination, would be required to clear up this possible discreparicy. We believe in the meantime that the nonelastic cross sections obtained by subtracting the integrated elastic-scattering cross sections from the total crosi: sections are more reliable and their error estimates realistic.

\section{CONCLUSION.}

The ENDF/B W (Mat 1060-63) elastic-scattering angular distributions are in agreement with our data at angles less than $50^{\circ}$ but disagree at larger angles. The ENDF/B angle-integrated elastic cross sections, however, are in general agreement with our data.

Inelastic scattering to the continumm is adequately described by a simple evaporation model employing a nuclear temperature, but total inelastic cross sections obtained from integrating the evaporaticn spectrum are higher than measured noneleastic cross sections by as much is $20 \%$. The ENDF/B Mat 1060-63 nuclear temperatures 1ie 10-15\% below experimental values from 4 to $9 \mathrm{MeV}$. 


\section{ACKNOWLEDGMENTS}

Many have contributed to this experimental program at one time or another and we would like to thank them for their contributions. In particular, we would like to acknowledge the help of J. K. Dickens, J. W. McConnell, J. A. Biggerstaff, A. M. Marusak, P. H. Stelson, C. 0. LeRigoleur, and E. Hungerford. 
REFERENCES

1. R. E. Textor and V. V. Verbinski, 05S: A Monte Carlo Code for Calculating Pulse Height Distribltions Due to Monoenergetic Neutrons Incident on Organic Scintillators, ORNL-4160 (February 1968).

2. W. E. Kinney. Nuc1. Instr. and Methods 83, 15 (1970).

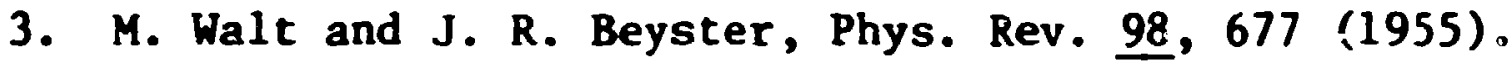

4. P. F. Rose, Atomics International, P. O. Box 309, Canoga Park, Cajifornia 91304, private communication.

5. R. W. Hill, Phys. Rev. 109, 2105 (1958).

6. B. Holmqvist and T. Wiedling, "Neutron Elastic Scattering Cross Sections. Experimental Data and Optical-Model Cross-Section Calculations," AKTIEBOLAGET ATOMENERGI Report AE-366 (June 1969).

7. S. G. Buccino, C. E. Hollandsworth, H. W. Lewis and P. R. Bevington, Nucl. Yhys. 60,17 (1964).

8. R. O. Gwens and J. H. Towle, Nuc1. Phys. Al12, 337 (1.968).

9. J. J. Devaney and P. G. Foster, Jr., An Evaluation of the Total Cross Section for Tungsten, LA-4928 (June 1972).

10. M. D. Goldberg, et al., Neutron Cross Sections, Volume $11 C, Z=61$ to 87 , BNL-325, Supplement 2 (August 1966). 


\section{APPENDIX}

Tabulated Values of Natural $W$ Neutron Elas: $1 c-$ and InelasticScattering Cross Sections from 4.34 to $8.56 \mathrm{MeV}$

In the following tables we give sur results fo: natural tungsten neutron elastic- and inelastic-scattering cross sections. We first tabulate the differential cross sections for elastic scattering including inelastic scattering to levels $\leq 0.123 \mathrm{MeV}$. The tabulated uncertainties are relative and do not 2 nclude $a \pm 7 \%$ uncertainty in detector efficiency which is common to all points. The angle uncertainty is $\pm 1^{\circ}$. The uncertainty in integrated cross sections do include the \pm 77 standard efficitncy error.

Cross sections for inelastic scattering to levels $>0.123 \mathrm{MeV}$ are given In the continuum tables as angle-averaged double-differential cross sections which are constant over $25 \mathrm{keV}$ intervals as shown fin Figure 5. The value In the $Q_{N}$ column $1 \varepsilon$ the upper 1 imit of the $25 \mathrm{keV}$ interval in $Q$ value (the lower limit of excitation energy). The continuum cross-section uncertainties do not include the $\pm 7 \%$ standard error in detzctor efficiency. 
Table Al. A Table of Contents for the $W$ Neutron Cross Section Tables

Quantity

Page No.

Elastic Scattering Plus Inelastic Scattering $23-27$

up to Levels $\leq 0.123 \mathrm{MeV}$

Continuum

$28-34$ 
JIATTERINE OF $4.34 \cdot$ ?R-0.07 MEV NEUTRONS FRIM $W$ LEYEL 151 0.0 MEV NEII $141 \quad 18$ HNGLES

0.100

0.111

0.123

$\begin{array}{cccc}\text { ANGLE } & X \text {-SEC. } & \text { ERROR } 10 / 0, & \text { RUN } \\ \text { CM } & \text { MB/STR } & + & -\end{array}$

MULTIPLE SCATTERING CORRECTION DONE

$\begin{array}{rrrrr}10.08 & 5.368 .92 & 4.0 & 7.0 & 26701 \\ 17.62 & 3950.79 & 6.1 & 9.6 & 26705 \\ 25.14 & 2284.66 & 4.6 & 6.4 & 10401 \\ 25.15 & 2418.84 & 6.0 & 11.1 & 26703 \\ 32.68 & 1120.87 & 5.2 & 9.3 & 10405 \\ 40.21 & 463.98 & 7.2 & 13.4 & 10403 \\ 47.74 & 205.91 & 7.3 & 9.7 & 15501 \\ 55.26 & 05.15 & 9.5 & 15.8 & 15505 \\ 62.78 & 60.93 & 14.0 & 23.9 & 15503 \\ 70.30 & 67.82 & 14.7 & 18.7 & 10901 \\ 77.81 & 70.78 & 9.7 & 19.9 & 10905 \\ 85.31 & 97.76 & 9.7 & 17.4 & 10903 \\ 95.32 & 126.81 & 7.8 & 9.1 & 14401 \\ 102.81 & 105.06 & 7.6 & 10.6 & 14405 \\ 110.30 & 70.32 & 13.4 & 14.2 & 14403 \\ 121.77 & 37.97 & 13.7 & 16.4 & 12501 \\ 129.25 & 34.15 & 18.3 & 19.8 & 12505 \\ 136.73 & 38.48 & 21.4 & 23.5 & 12503\end{array}$

AVERAGE $X$-SEC $0.0 \mathrm{MB} / \mathrm{STR} 0$ NOTE

INTEGRATED $X$-SEC 4432.75 MB ERROR 7.4 FER IENT

P 9 FIT

COEF. ERROR IO/ÜI

0
1
2
3
4
5
15
7
8

$\begin{array}{rr}705.49536 & 2.5 \\ 525.88184 & 3.0 \\ 422.14502 & 3.3 \\ 333.70416 & 3.4 \\ 241.92575 & 4.1 \\ 143.97351 & 5.6 \\ 79.75507 & 8.0 \\ 47.38870 & 10.7 \\ 21.09935 & 16.3 \\ 5.68121 & 40.4\end{array}$




\begin{tabular}{|c|c|c|c|c|c|}
\hline \multicolumn{2}{|c|}{ SCATIERINE OF } & \multirow{2}{*}{\multicolumn{2}{|c|}{ MEV NEY I 141}} & \multicolumn{2}{|r|}{ SOMC CPOM } \\
\hline LEVEL IS! & $\begin{array}{l}0.0 \\
0.100 \\
0.111 \\
0.123\end{array}$ & & & \multicolumn{2}{|c|}{21 ANCLES } \\
\hline $\begin{array}{l}\text { ANGLE } \\
\text { CM }\end{array}$ & $\begin{array}{l}X \text {-SEC. } \\
\text { MB/STR }\end{array}$ & \multicolumn{3}{|c|}{$\begin{array}{c}\text { ERROR } 10 / 01 \\
+\end{array}$} & RUN \\
\hline \multicolumn{6}{|c|}{ MULTIPLE SCATTERING CORRECTION DONE } \\
\hline $\begin{array}{r}10.06 \\
15.09 \\
17.60 \\
22.64 \\
25.14 \\
25.14 \\
30.17 \\
32.68 \\
40.20 \\
47.74 \\
55.26 \\
62.78 \\
70.30 \\
77.81 \\
85.32 \\
95.32 \\
102.81 \\
110.30 \\
121.77 \\
129.24 \\
136.72\end{array}$ & $\begin{array}{r}5154.44 \\
4115.51 \\
3727.87 \\
2431.48 \\
1863.92 \\
1909.34 \\
1061.56 \\
812.08 \\
322.76 \\
195.00 \\
126.19 \\
70.70 \\
66.46 \\
87.82 \\
120.51 \\
117.77 \\
88.66 \\
52.89 \\
23.23 \\
30.23 \\
43.49\end{array}$ & $\begin{array}{l}3.9 \\
4.6 \\
4.6 \\
7.4 \\
6.0 \\
4.5 \\
8.9 \\
6.5 \\
8.1 \\
7.0 \\
10.1 \\
11.0 \\
12.9 \\
12.4 \\
10.3 \\
8.5 \\
8.4 \\
11.8 \\
25.6 \\
20.5 \\
15.9\end{array}$ & \multicolumn{2}{|c|}{$\begin{array}{r}5.2 \\
6.7 \\
7.9 \\
7.4 \\
9.2 \\
5.3 \\
9.6 \\
8.7 \\
14.0 \\
8.3 \\
10.0 \\
16.1 \\
15.7 \\
13.1 \\
10.8 \\
8.9 \\
8.3 \\
8.4 \\
19.1 \\
13.4 \\
11.8\end{array}$} & $\begin{array}{r}2590 ! \\
24901 \\
25905 \\
24905 \\
25903 \\
9101 \\
24903 \\
9105 \\
9103 \\
2201 \\
2205 \\
2203 \\
3601 \\
3605 \\
3603 \\
7201 \\
7205 \\
7203 \\
5301 \\
5305 \\
6303\end{array}$ \\
\hline AVERAGE & E $X$-SEC & 0.0 & \multicolumn{2}{|c|}{$M B / S T R$} & NOTE \\
\hline INTEGRATEI & $D x-5 E C$ & 3923.41 & $\mathrm{MB}$ & ERROR & 7.2 PER LENT \\
\hline P10 F & IT & & & & \\
\hline$L$ & \multicolumn{2}{|c|}{ COEF . } & ERF & OR $10 / 0)$ & \\
\hline $\begin{array}{r}0 \\
1 \\
2 \\
3 \\
4 \\
5 \\
6 \\
7 \\
8 \\
9 \\
10\end{array}$ & \multicolumn{2}{|c|}{$\begin{array}{r}624.43066 \\
460.44873 \\
367.57446 \\
296.88379 \\
229.01265 \\
151.29405 \\
90.53791 \\
62.68361 \\
36.10461 \\
14.85574 \\
4.30727\end{array}$} & & $\begin{array}{r}1.9 \\
2.3 \\
2.5 \\
2.6 \\
3.0 \\
4.0 \\
5.7 \\
6.7 \\
9.3 \\
15.9 \\
37.3\end{array}$ & \\
\hline
\end{tabular}


SCATIERING OF 5.44 +OR-0.07 MEV NEUTRONS FROM $\mathrm{h}$

LEVEL 151 0.0 MEV REY1 14117 ANGLES

0.100

0.111

0.123

ANGLE $X$-SEC. ERROR $I[J / 0 I$ RUN

CM MB/STR +

MULTIPLE SCATIERING CORRECTION DONE

$\begin{array}{rrrrr}15.08 & 3562.83 & 6.6 & 5.8 & 50502 \\ 22.63 & 1536.66 & 6.2 & 7.2 & 30502 \\ 27.65 & 853.64 & 4.7 & 6.1 & 50203 \\ 35.18 & 263.98 & 8.1 & 7.4 & 30203 \\ 42.71 & 180.24 & 8.1 & 9.2 & 10203 \\ 47.73 & 193.51 & 6.8 & 5.9 & 50187 \\ 55.26 & 151.49 & 8.6 & 6.9 & 30187 \\ 62.78 & 79.84 & 10.4 & 7.6 & 10187 \\ 70.30 & 43.85 & 25.6 & 11.8 & 50126 \\ 77.80 & 50.24 & 12.9 & 9.6 & 30126 \\ 85.31 & 68.24 & 10.6 & 7.3 & 10126 \\ 92.81 & 87.02 & 8.2 & 10.5 & 50142 \\ 100.31 & 66.03 & 10.5 & 6.8 & 30142 \\ 107.80 & 43.42 & 17.7 & 8.4 & 10142 \\ 119.77 & 19.49 & 24.3 & 21.5 & 50156 \\ 127.25 & 18.14 & 35.9 & 13.9 & 30156 \\ 134.72 & 32.60 & 13.8 & 8.4 & 10156\end{array}$

qVERACE $X$-SEC $0.0 \mathrm{MB} / \mathrm{STR}$ D NOTE

INTEGRATED X-SEC 2912.43 MS ERROR 7.6 PER IENT

PII FIT

L COEF. ERROR IO/OI

$\begin{array}{rrr}0 & 463.52808 & 3.0 \\ 1 & 351.02710 & 3.9 \\ 2 & 283.23364 & 4.3 \\ 3 & 233.18773 & 4.8 \\ 4 & 186.09500 & 5.3 \\ 5 & 139.27782 & 5.9 \\ 6 & 100.47435 & 7.0 \\ 7 & 77.37817 & 6.9 \\ 8 & 49.72884 & 8.5 \\ 0 & 24.03671 & 12.2 \\ 11 & 9.65919 & 20.4 \\ 11 & 2.05970 & 67.2\end{array}$


SLAIIERING OF 7.54 - OR-0.01 MEV NEUTFONS FRIOM $W$ LEVEL ISI 0.0 MEV NEI I 14117 ANGLES 0.100 0.111 0.123

$\begin{array}{clcc}\text { ANGLE } & X \text {-SEC. } & \text { ERROR 10/0I } & \text { RUN } \\ \text { MB } & \text { MB/STR } & + & -\end{array}$ MUL TIPLE SCATTERING CORRECT!ON DONE

$\begin{array}{rrrrr}15.09 & 3554.19 & 4.5 & 4.0 & 50525 \\ 22.62 & 1448.38 & 5.2 & 6.4 & 30525 \\ 21.64 & 539.10 & 6.6 & 5.4 & 50111 \\ 35.18 & 143.97 & 10.5 & 7.9 & 30111 \\ 42.71 & 208.13 & 7.2 & 6.8 & 10111 \\ 4 i .73 & 223.48 & 6.5 & 7.0 & 50110 \\ 55.26 & 156.72 & 8.8 & 7.7 & 30110 \\ 62.78 & 60.03 & 12.4 & 11.9 & 10110 \\ 70.30 & 37.94 & 18.3 & 12.6 & 50107 \\ 77.81 & 65.07 & 12.5 & 8.6 & 30107 \\ 85.31 & 72.12 & 10.3 & 7.6 & 10107 \\ 92.81 & 67.27 & 12.2 & 7.6 & 50102 \\ 100.31 & 42.39 & 14.4 & 9.7 & 30102 \\ 107.80 & 21.45 & 17.9 & 14.7 & 10102 \\ 119.77 & 20.64 & 23.9 & 17.1 & 50099 \\ 127.25 & 22.23 & 26.4 & 12.6 & 30099 \\ 134.73 & 26.45 & 14.4 & 14.2 & 10099\end{array}$

AVERAGE $X$-SEC $0.0 \mathrm{MB} /$ STR D NOTE

INTEGRATED $X$-SEC 2813.24 MB ERROR 7.5 FER I.ENT FI2 FIT

$\begin{array}{ccc}L & \text { COEF. } & \text { ERRORIC/OI } \\ 0 & 447.74219 & 2.6 \\ 1 & 348.54272 & 3.1 \\ 2 & 287.14600 & 3.5 \\ 3 & 238.80631 & 3.8 \\ 4 & 200.20261 & 4.0 \\ 5 & 162.08463 & 4.4 \\ 6 & 125.31064 & 4.0 \\ 7 & 101.31007 & 5.1 \\ 8 & 74.65388 & 5.3 \\ 9 & 45.94987 & 7.0 \\ 10 & 21.71886 & 11.4 \\ 11 & 7.99819 & 20.9 \\ 12 & 2.27529 & 51.6\end{array}$


SCATIERING OF $8.56+0 R-0.06$ MEV NEUTRONS FROM $W$ $\begin{array}{ll}\text { LEVEL ISI } & 0.0 \text { MEI KEI I } 141 \text { 21 ANCLES } \\ & 0.100 \\ & 0.111 \\ & 0.123\end{array}$

$\begin{array}{clcc}\text { ANGLE } & X \text {-SEC. } & \text { ERROR I0/0I } & \text { RUN } \\ \text { MM } & \text { MB/STR } & + & -\end{array}$

MULTIPLE SCATTERING CORRECTION DONE

$\begin{array}{rrrrr}10.06 & 4975.68 & 4.9 & 8.3 & 50554 \\ 15.09 & 3379.45 & 5.4 & 7.0 & 50548 \\ 22.62 & 1219.54 & 6.8 & 8.6 & 30548 \\ 27.65 & 359.12 & 8.1 & 9.2 & 50204 \\ 31.67 & 140.78 & 11.6 & 8.5 & 50321 \\ 35.18 & 133.58 & 10.0 & 8.4 & 30204 \\ 39.20 & 187.40 & 9.5 & 7.0 & 30321 \\ 42.72 & 241.94 & 7.3 & 7.9 & 10204 \\ 46.72 & 239.40 & 8.5 & 6.1 & 10321 \\ 47.73 & 266.93 & 8.8 & 5.7 & 50267 \\ 55.26 & 168.42 & 8.7 & 6.5 & 30267 \\ 62.78 & 57.28 & 14.3 & 6.7 & 10267 \\ 70.29 & 43.09 & 11.6 & 8.9 & 50234 \\ 77.80 & 71.79 & 9.3 & 8.3 & 30234 \\ 85.32 & 81.56 & 13.6 & 8.2 & 10234 \\ 92.81 & 64.30 & 12.0 & 13.1 & 50285 \\ 100.31 & 31.06 & 14.2 & 10.3 & 30285 \\ 107.80 & 19.40 & 13.9 & 14.6 & 10285 \\ 19.77 & 24.59 & 14.6 & 17.5 & 50239 \\ 127.25 & 23.74 & 14.8 & 21.9 & 30239 \\ 19.73 & 21.22 & 16.4 & 18.4 & 10239\end{array}$

AVERAGE $X$-SEC D.O MB/STR O NOTE

INTEGRATED $X$-SEC $2632.13 \mathrm{MB}$ ERROP 7.5 PER IENT

$\begin{array}{ccc}\text { P13 FIT } & & \\ L & \text { COEF. } & \text { ERROR } 10 / 01 \\ 0 & 418.91699 & 2.8 \\ 1 & 326.69092 & 3.3 \\ 2 & 260.81812 & 3.9 \\ 3 & 218.84288 & 4.3 \\ 4 & 185.71191 & 4.5 \\ 5 & 153.97954 & 4.7 \\ 6 & 125.28264 & 4.8 \\ 7 & 102.55858 & 4.8 \\ 8 & 82.04819 & 5.0 \\ 9 & 54.11766 & 5.9 \\ 10 & 27.88792 & 9.2 \\ 11 & 11.61932 & 16.6 \\ 12 & 4.43031 & 31.9 \\ 13 & 1.37465 & 63.3\end{array}$




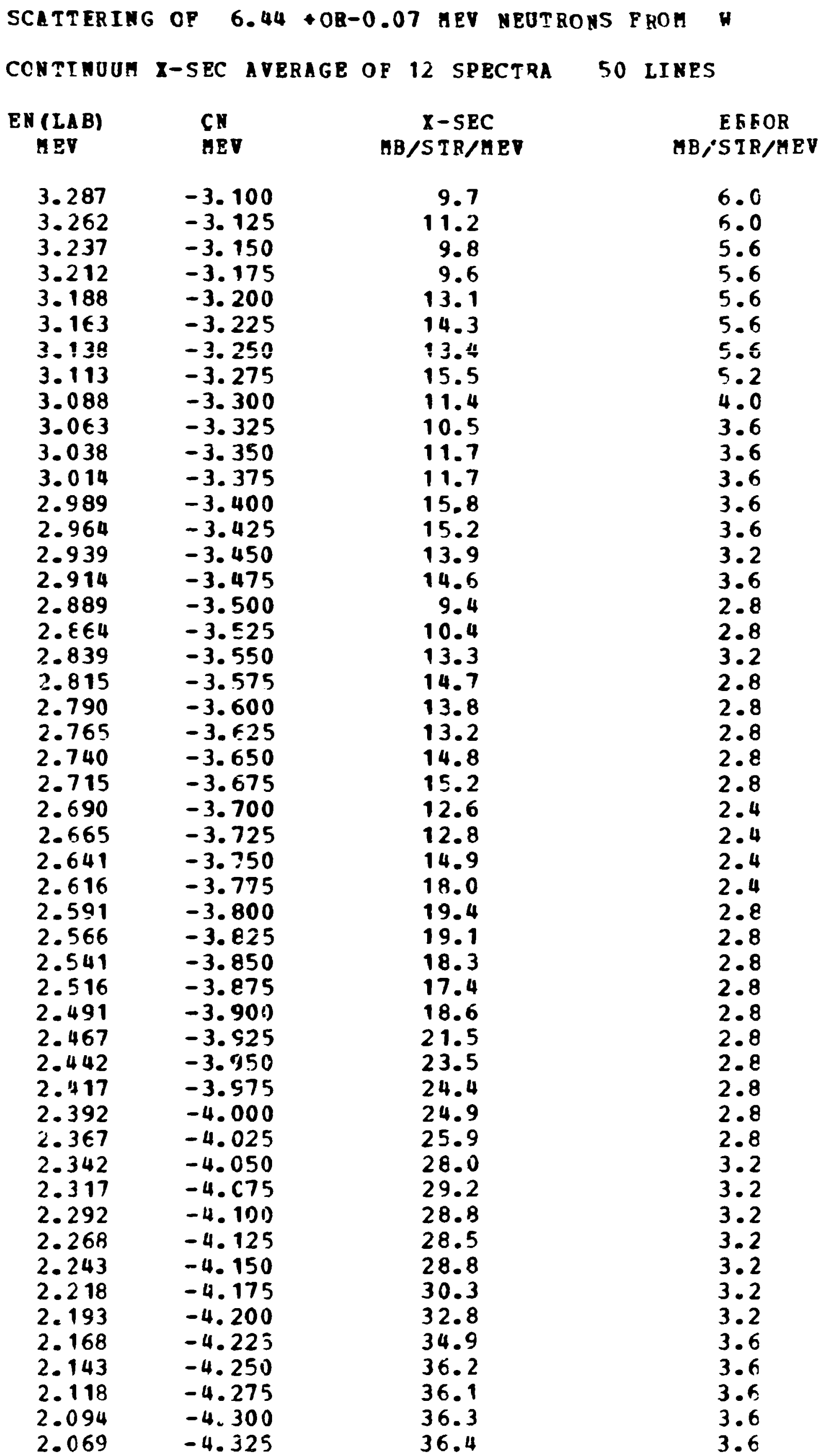


SCATTERING OP $5.44+0 R-0.07$ AEV NEUTRONS FROM CONTINUOH X-SEC ATRRAGE OP 12 SPSCTRA 38 LINES

\begin{tabular}{|c|c|c|c|}
\hline $\begin{array}{c}\text { EN (LA B) } \\
\text { nEV }\end{array}$ & $\begin{array}{l}\text { CN } \\
\text { HEV }\end{array}$ & $\begin{array}{c}X-S E C \\
H B / S I R / A E V\end{array}$ & $\begin{array}{c}\text { EREOR } \\
\text { MB/STB/HEV }\end{array}$ \\
\hline $\begin{array}{l}2.044 \\
2.019 \\
1.994 \\
1.969 \\
1.944 \\
1.920 \\
1.895 \\
1.870 \\
1.845 \\
1.820 \\
1.795 \\
1.770 \\
1.745 \\
1.721 \\
1.696 \\
1.671 \\
1.646 \\
1.621 \\
1.596 \\
1.571 \\
1.547 \\
1.522 \\
1.497 \\
1.472 \\
1.447 \\
1.422 \\
1.397 \\
1.372 \\
1.348 \\
1.323 \\
1.298 \\
1.273 \\
1.248 \\
1.223 \\
1.198 \\
1.174 \\
1.149 \\
1.124\end{array}$ & $\begin{array}{l}-4.350 \\
-4.375 \\
-4.400 \\
-4.425 \\
-4.450 \\
-4.475 \\
-4.500 \\
-4.525 \\
-4.550 \\
-4.575 \\
-4.500 \\
-4.625 \\
-4.650 \\
-4.675 \\
-4.700 \\
-4.725 \\
-4.750 \\
-4.775 \\
-4.800 \\
-4.825 \\
-4.850 \\
-4.875 \\
-4.500 \\
-4.925 \\
-4.950 \\
-4.975 \\
-5.000 \\
-5.025 \\
-5.050 \\
-5.075 \\
-5.100 \\
-5.125 \\
-5.150 \\
-5.175 \\
-5.200 \\
-5.225 \\
-5.250 \\
-5.275\end{array}$ & $\begin{array}{l}37.5 \\
39.5 \\
40.1 \\
38.6 \\
37.9 \\
39.8 \\
43.8 \\
45.8 \\
45.5 \\
47.1 \\
49.8 \\
53.2 \\
55.7 \\
57.2 \\
56.5 \\
53.8 \\
52.4 \\
54.6 \\
60.4 \\
65.6 \\
68.9 \\
69.6 \\
69.7 \\
71.1 \\
73.9 \\
78.2 \\
78.2 \\
77.9 \\
81.6 \\
90.5 \\
95.2 \\
95.2 \\
98.4 \\
99.9 \\
99.2 \\
108.0 \\
101.1 \\
117.4\end{array}$ & $\begin{array}{l}3.6 \\
3.6 \\
4.0 \\
3.6 \\
3.6 \\
4.0 \\
4.0 \\
4.0 \\
4.4 \\
4.4 \\
4.4 \\
4.8 \\
4.9 \\
5.2 \\
5.2 \\
5.2 \\
5.2 \\
5.2 \\
5.6 \\
6.0 \\
6.4 \\
6.8 \\
7.2 \\
7.2 \\
8.0 \\
8.4 \\
8.8 \\
9.2 \\
10.0 \\
11.2 \\
12.4 \\
13.2 \\
14.0 \\
14.8 \\
15.6 \\
18.8 \\
20.4 \\
25.6\end{array}$ \\
\hline
\end{tabular}


SCATTERIMG OP 7.54 +OR-0.06 GEV MEOTRONS PRCY COMTIMUOA X-SBC AVERAGE OF 13 SPECTRA 50 LIAES

\begin{tabular}{|c|c|c|c|}
\hline$\underset{\text { IIET }}{E \text { (LAB) }}$ & $\begin{array}{l}\text { GN } \\
\text { HEV }\end{array}$ & $\begin{array}{c}X-S E C \\
\mathrm{HB} / \mathrm{STR} / \mathrm{MEV}\end{array}$ & $\begin{array}{c}\text { EBROR } \\
\text { GB/STR/AEV }\end{array}$ \\
\hline $\begin{array}{l}3.629 \\
3.604 \\
3.579 \\
3.555 \\
3.530 \\
3.505 \\
3.480 \\
3.455 \\
3.430 \\
3.405 \\
3.381 \\
3.356 \\
3.331 \\
3.306 \\
3.281 \\
3.256 \\
3.231 \\
3.206 \\
3.182 \\
3.157 \\
3.132 \\
3.107 \\
3.082 \\
3.057 \\
3.032 \\
3.008 \\
2.983 \\
2.958 \\
2.933 \\
2.908 \\
2.883 \\
2.858 \\
2.834 \\
2.809 \\
2.784 \\
2.759 \\
2.734 \\
2.709 \\
2.684 \\
2.659 \\
2.635 \\
2.610 \\
2.585 \\
2.560 \\
2.535 \\
2.510 \\
2.485 \\
2.461 \\
2.436 \\
2.411\end{array}$ & $\begin{array}{l}-3.850 \\
-3.875 \\
-3.900 \\
-3.925 \\
-3.950 \\
-3.975 \\
-4.000 \\
-4.025 \\
-4.050 \\
-4.075 \\
-4.100 \\
-4.125 \\
-4.150 \\
-4.175 \\
-4.200 \\
-4.225 \\
-4.250 \\
-4.275 \\
-4.300 \\
-4.325 \\
-4.350 \\
-4.375 \\
-4.400 \\
-4.425 \\
-4.450 \\
-4.475 \\
-4.500 \\
-4.525 \\
-4.550 \\
-4.575 \\
-4.600 \\
-4.625 \\
-4.650 \\
-4.675 \\
-4.700 \\
-4.725 \\
-4.750 \\
-4.775 \\
-4.800 \\
-4.825 \\
-4.850 \\
-4.975 \\
-4.900 \\
-4.925 \\
-4.950 \\
-4.975 \\
-4.000 \\
-5.025 \\
-5.050 \\
-3.075\end{array}$ & $\begin{array}{r}16.5 \\
22.2 \\
10.4 \\
9.5 \\
9.1 \\
10.0 \\
11.8 \\
11.6 \\
8.5 \\
1.4 \\
9.0 \\
6.3 \\
9.4 \\
10.3 \\
11.9 \\
13.8 \\
11.4 \\
8.6 \\
9.6 \\
8.5 \\
9.6 \\
10.5 \\
12.4 \\
16.2 \\
13.7 \\
10.4 \\
12.0 \\
13.0 \\
16.5 \\
16.8 \\
16.0 \\
17.2 \\
17.7 \\
15.8 \\
15.6 \\
15.7 \\
18.0 \\
22.6 \\
23.5 \\
18.1 \\
17.9 \\
21.6 \\
25.6 \\
24.1 \\
22.8 \\
23.7 \\
26.8 \\
26.5 \\
24.8 \\
27.0\end{array}$ & $\begin{array}{l}10.4 \\
10.0 \\
7.2 \\
5.6 \\
5.2 \\
4.4 \\
4.4 \\
4.4 \\
4.4 \\
4.8 \\
5.2 \\
4.0 \\
4.4 \\
4.0 \\
4.4 \\
4.0 \\
3.6 \\
3.6 \\
4.0 \\
4.0 \\
4.0 \\
3.6 \\
3.6 \\
4.0 \\
3.6 \\
3.2 \\
3.6 \\
3.6 \\
3.6 \\
3.2 \\
3.6 \\
3.2 \\
3.2 \\
3.2 \\
3.6 \\
3.6 \\
3.6 \\
3.6 \\
4.0 \\
3.6 \\
3.6 \\
3.6 \\
3.6 \\
3.6 \\
4.0 \\
4.0 \\
4.0 \\
4.0 \\
4.0 \\
4.0\end{array}$ \\
\hline
\end{tabular}


SCATTERING OP $7.54+08-0.06$ MEV NEUTRONS FROA CONTINUUA X-SEC AVERAGE OF 13 SPECTRA 50 LIMES

\begin{tabular}{|c|c|c|c|}
\hline $\begin{array}{c}\text { EA (LAB) } \\
\text { HEV }\end{array}$ & $\begin{array}{l}\text { CN } \\
\text { UEV }\end{array}$ & $\begin{array}{c}X-S E C \\
\text { HB/STR/AEV }\end{array}$ & $\begin{array}{c}\text { EEEGR } \\
\text { HB/STR/AEV }\end{array}$ \\
\hline $\begin{array}{l}2.386 \\
2.361 \\
2.336 \\
2.311 \\
2.287 \\
2.262 \\
2.237 \\
2.212 \\
2.187 \\
2.162 \\
2.137 \\
2.112 \\
2.088 \\
2.063 \\
2.038 \\
2.013 \\
1.988 \\
1.963 \\
1.938 \\
1.914 \\
1.889 \\
1.864 \\
1.839 \\
1.814 \\
1.789 \\
1.764 \\
1.740 \\
1.715 \\
1.690 \\
1.665 \\
1.640 \\
1.615 \\
1.590 \\
1.565 \\
1.541 \\
1.516 \\
1.491 \\
1.466 \\
1.441 \\
1.416 \\
1.391 \\
1.367 \\
1.342 \\
1.317 \\
1.292 \\
1.267 \\
1.242 \\
1.217 \\
1.192 \\
1.168\end{array}$ & $\begin{array}{l}-5.100 \\
-5.125 \\
-5.150 \\
-5.175 \\
-5.200 \\
-5.225 \\
-5.250 \\
-5.275 \\
-5.300 \\
-5.325 \\
-5.350 \\
-5.375 \\
-5.400 \\
-6.425 \\
-5.450 \\
-5.475 \\
-5.500 \\
-5.525 \\
-5.550 \\
-5.575 \\
-5.600 \\
-5.625 \\
-5.650 \\
-5.675 \\
-5.700 \\
-5.725 \\
-5.750 \\
-5.775 \\
-5.800 \\
-5.825 \\
-5.850 \\
-5.875 \\
-5.900 \\
-5.925 \\
-5.950 \\
-5.975 \\
-6.000 \\
-6.025 \\
-6.050 \\
-6.075 \\
-6.100 \\
-6.125 \\
-6.150 \\
-6.175 \\
-6.200 \\
-6.225 \\
-6.250 \\
-6.275 \\
-6.301 \\
-6.325\end{array}$ & $\begin{array}{r}32.7 \\
34.2 \\
29.2 \\
27.8 \\
30.3 \\
33.6 \\
32.3 \\
30.4 \\
35.3 \\
40.4 \\
37.9 \\
33.1 \\
33.0 \\
39.1 \\
45.7 \\
47.0 \\
46.2 \\
44.4 \\
46.8 \\
53.1 \\
57.9 \\
54.2 \\
46.6 \\
46.5 \\
53.2 \\
61.3 \\
61.0 \\
59.2 \\
63.1 \\
66.3 \\
69.2 \\
69.8 \\
71.6 \\
72.5 \\
71.2 \\
70.5 \\
71.5 \\
71.1 \\
72.4 \\
79.3 \\
86.6 \\
86.2 \\
81.5 \\
83.4 \\
92.5 \\
100.8 \\
98.5 \\
97.0 \\
103.9\end{array}$ & $\begin{array}{l}4.4 \\
4.4 \\
4.0 \\
4.4 \\
4.4 \\
4.4 \\
4.4 \\
4.4 \\
4.4 \\
4.4 \\
4.4 \\
4.4 \\
4.4 \\
4.8 \\
4.8 \\
4.8 \\
4.8 \\
5.2 \\
5.2 \\
5.6 \\
5.6 \\
5.6 \\
5.2 \\
5.2 \\
5.6 \\
6.0 \\
6.0 \\
6.0 \\
6.4 \\
6.4 \\
6.8 \\
6.8 \\
7.2 \\
7.6 \\
7.6 \\
8.0 \\
8.4 \\
8.4 \\
8.8 \\
9.6 \\
10.4 \\
10.8 \\
11.2 \\
11.6 \\
13.2 \\
14.0 \\
15.2 \\
15.6 \\
16.4 \\
19.6\end{array}$ \\
\hline
\end{tabular}


SCATTERIMG OP $8.56+C R-0.06$ GEV WEUTBONS PROA CONTIMOOA I-SBC ATERAGE OF 15 SPECTRA 50 LIMES

\begin{tabular}{|c|c|c|c|}
\hline $\begin{array}{c}\text { EE (LAB) } \\
\text { GET }\end{array}$ & $\begin{array}{l}\text { CN } \\
\text { GEV }\end{array}$ & $\begin{array}{c}\text { X-SEC } \\
\text { PB/STR/HEV }\end{array}$ & $\begin{array}{c}\text { EBEOR } \\
\text { GB/STB/AEV }\end{array}$ \\
\hline $\begin{array}{l}4.340 \\
4.315 \\
4.290 \\
4.265 \\
4.240 \\
4.215 \\
4.191 \\
4.166 \\
4.141 \\
4.116 \\
4.091 \\
4.066 \\
4.041 \\
4.017 \\
3.992 \\
3.967 \\
3.942 \\
3.917 \\
3.892 \\
3.867 \\
3.842 \\
3.818 \\
3.793 \\
3.768 \\
3.743 \\
3.718 \\
3.693 \\
3.668 \\
3.644 \\
3.619 \\
3.594 \\
3.569 \\
3.544 \\
3.519 \\
3.494 \\
3.470 \\
3.445 \\
3.420 \\
3.395 \\
3.370 \\
3.345 \\
3.320 \\
3.295 \\
3.271 \\
3.246 \\
3.221 \\
3.196 \\
3.171 \\
3.146 \\
3.121\end{array}$ & $\begin{array}{l}-4.150 \\
-4.175 \\
-4.200 \\
-4.225 \\
-4.250 \\
-4.275 \\
-4.300 \\
-4.325 \\
-4.350 \\
-4.375 \\
-4.400 \\
-4.425 \\
-4.450 \\
-4.475 \\
-4.500 \\
-4.525 \\
-4.550 \\
-4.575 \\
-4.600 \\
-4.625 \\
-4.650 \\
-4.675 \\
-4.675 \\
-4.700 \\
-4.725 \\
-4.750 \\
-4.775 \\
-4.800 \\
-4.825 \\
-4.850 \\
-4.875 \\
-4.900 \\
-4.925 \\
-4.950 \\
-4.975 \\
-4.000 \\
-5.025 \\
-5.650 \\
-5.075 \\
-5.100 \\
-5.125 \\
-5.150 \\
-5.175 \\
-5.200 \\
-5.225 \\
-5.250 \\
-5.275 \\
-5.300 \\
-5.325 \\
-5.350 \\
-5.375\end{array}$ & $\begin{array}{r}8.3 \\
10.2 \\
9.0 \\
11.6 \\
11.8 \\
9.7 \\
11.4 \\
10.8 \\
7.3 \\
6.2 \\
6.7 \\
7.8 \\
7.8 \\
9.0 \\
9.6 \\
8.3 \\
11.0 \\
11.6 \\
9.0 \\
7.5 \\
7.0 \\
7.7 \\
11.4 \\
10.9 \\
11.3 \\
11.9 \\
12.5 \\
13.1 \\
9.5 \\
10.2 \\
12.1 \\
11.7 \\
12.6 \\
10.7 \\
12.2 \\
10.5 \\
12.6 \\
14.8 \\
18.0 \\
19.0 \\
16.1 \\
13.4 \\
14.9 \\
17.8 \\
18.6 \\
16.4 \\
14.6 \\
16.7 \\
16.9 \\
15.2\end{array}$ & $\begin{array}{l}6.0 \\
6.0 \\
4.8 \\
4.8 \\
5.2 \\
5.2 \\
4.8 \\
4.8 \\
4.0 \\
4.0 \\
4.0 \\
4.0 \\
4.0 \\
3.2 \\
3.6 \\
3.6 \\
4.0 \\
4.0 \\
3.6 \\
3.6 \\
3.6 \\
3.2 \\
3.2 \\
2.8 \\
2.8 \\
2.8 \\
2.8 \\
2.8 \\
2.8 \\
2.8 \\
2.8 \\
2.4 \\
2.8 \\
2.8 \\
2.8 \\
2.8 \\
2.8 \\
2.8 \\
2.8 \\
2.8 \\
2.8 \\
2.8 \\
2.8 \\
2.8 \\
2.8 \\
2.8 \\
2.8 \\
2.8 \\
2.8 \\
2.8\end{array}$ \\
\hline
\end{tabular}


SCATTERING OF $8.56+0 R-0.06$ MEV MEUTROHS FBOH

CONTIMOUA X-SEC AVERAGE 0 F 15 SPECTRA 50 LINES

\begin{tabular}{|c|c|c|c|}
\hline $\begin{array}{c}\text { EN (LAB) } \\
G E T\end{array}$ & $\begin{array}{l}\text { GI } \\
\text { GEV }\end{array}$ & $\begin{array}{c}X-S E C \\
n B / S T R / \Delta E V\end{array}$ & $\begin{array}{c}\text { ERFOR } \\
\text { GB/STR/HEV }\end{array}$ \\
\hline $\begin{array}{l}3.097 \\
3.072 \\
3.047 \\
3.022 \\
2.997 \\
2.972 \\
2.947 \\
2.922 \\
2.898 \\
2.873 \\
2.848 \\
2.823 \\
2.798 \\
2.773 \\
2.748 \\
2.724 \\
2.699 \\
2.674 \\
2.649 \\
2.624 \\
2.599 \\
2.574 \\
2.550 \\
2.525 \\
2.500 \\
2.475 \\
2.450 \\
2.425 \\
2.400 \\
2.375 \\
2.351 \\
2.326 \\
2.301 \\
2.276 \\
2.251 \\
2.226 \\
2.201 \\
2.177 \\
2.152 \\
2.127 \\
2.102 \\
2.077 \\
2.052 \\
2.027 \\
2.003 \\
1.978 \\
1.953 \\
1.928 \\
1.903 \\
1.878\end{array}$ & $\begin{array}{l}-5.400 \\
-5.425 \\
-5.450 \\
5.475 \\
-5.510 \\
-5.525 \\
-5.550 \\
-5.575 \\
-5.600 \\
-5.625 \\
-5.550 \\
-5.675 \\
-5.700 \\
-5.725 \\
-5.750 \\
-5.775 \\
-5.800 \\
-5.825 \\
-5.850 \\
-5.875 \\
-5.900 \\
-5.925 \\
-5.950 \\
-5.575 \\
-6.000 \\
-6.025 \\
-6.050 \\
-6.075 \\
-6.100 \\
-6.125 \\
-6.150 \\
-6.175 \\
-6.200 \\
-6.225 \\
-6.250 \\
-6.275 \\
-6.300 \\
-6.325 \\
-6.350 \\
-6.375 \\
-6.400 \\
-6.425 \\
-6.450 \\
-6.475 \\
-6.500 \\
-6.525 \\
-6.550 \\
-6.575 \\
-6.600 \\
-6.625\end{array}$ & $\begin{array}{l}13.4 \\
18.2 \\
23.4 \\
25.6 \\
23.3 \\
22.2 \\
24.6 \\
26.9 \\
27.7 \\
27.7 \\
28.2 \\
26.6 \\
25.0 \\
24.3 \\
27.8 \\
28.1 \\
27.6 \\
27.2 \\
28.8 \\
31.3 \\
33.0 \\
32.1 \\
33.3 \\
34.9 \\
35.0 \\
32.7 \\
31.7 \\
34.1 \\
36.8 \\
37.1 \\
35.8 \\
35.2 \\
36.9 \\
41.1 \\
43.9 \\
41.6 \\
40.8 \\
42.1 \\
45.7 \\
49.4 \\
52.8 \\
53.7 \\
52.4 \\
49.2 \\
47.8 \\
49.6 \\
53.3 \\
55.4 \\
55.9 \\
55.9\end{array}$ & $\begin{array}{l}2.8 \\
2.8 \\
2.8 \\
2.8 \\
3.2 \\
3.2 \\
3.2 \\
3.2 \\
3.2 \\
3.2 \\
3.2 \\
3.2 \\
3.2 \\
3.2 \\
3.2 \\
3.2 \\
3.2 \\
3.2 \\
3.2 \\
3.2 \\
3.6 \\
3.2 \\
3.6 \\
3.6 \\
3.6 \\
3.6 \\
3.6 \\
3.6 \\
3.6 \\
3.6 \\
3.6 \\
3.6 \\
3.6 \\
4.0 \\
4.0 \\
4.0 \\
4.0 \\
4.0 \\
4.0 \\
4.4 \\
4.4 \\
4.4 \\
4.4 \\
4.4 \\
4.4 \\
4.4 \\
4.8 \\
4.8 \\
4.8 \\
4.8\end{array}$ \\
\hline
\end{tabular}




\begin{tabular}{|c|c|c|c|c|}
\hline CONTInOOH & I-SEC IVERAGE & OP 15 SPECTRA & 26 & LINES \\
\hline $\begin{array}{c}\text { EY (LD B) } \\
\text { MEV }\end{array}$ & GE & $\begin{array}{c}X-S E C \\
\text { UB/STR/AEV }\end{array}$ & & $\begin{array}{c}\text { EBEOR } \\
\text { UB/STB/AEV }\end{array}$ \\
\hline $\begin{array}{l}1.853 \\
1.828 \\
1.804 \\
1.779 \\
1.754 \\
1.729 \\
1.704 \\
1.679 \\
1.654 \\
1.630 \\
1.605 \\
1.580 \\
1.555 \\
1.530 \\
1.505 \\
1.480 \\
1.456 \\
1.431 \\
1.406 \\
1.381 \\
1.356 \\
1.331 \\
1.306 \\
1.281 \\
1.257 \\
1.232\end{array}$ & $\begin{array}{l}-6.650 \\
-6.675 \\
-6.700 \\
-6.725 \\
-6.750 \\
-6.775 \\
-6.800 \\
-6.825 \\
-6.850 \\
-6.875 \\
-6.900 \\
-6.925 \\
-6.950 \\
-6.975 \\
-7.000 \\
-7.025 \\
-7.050 \\
-7.675 \\
-7.100 \\
-7.125 \\
-7.150 \\
-7.175 \\
-7.200 \\
-7.225 \\
-7.250 \\
-7.275\end{array}$ & $\begin{array}{l}57.3 \\
60.2 \\
63.6 \\
66.2 \\
69.4 \\
72.3 \\
74.5 \\
75.1 \\
77.6 \\
79.6 \\
83.3 \\
86.1 \\
89.8 \\
92.3 \\
92.4 \\
90.9 \\
90.6 \\
93.6 \\
96.3 \\
98.8 \\
103.2 \\
110.8 \\
116.2 \\
113.9 \\
112.0 \\
124.8\end{array}$ & & $\begin{array}{l}5.2 \\
5.2 \\
5.6 \\
5.6 \\
6.0 \\
6.0 \\
6.4 \\
6.4 \\
6.8 \\
6.8 \\
7.2 \\
7.6 \\
8.0 \\
8.8 \\
8.8 \\
9.2 \\
9.6 \\
10.0 \\
10.4 \\
11.2 \\
12.4 \\
13.6 \\
15.2 \\
15.2 \\
16.0 \\
18.0\end{array}$ \\
\hline
\end{tabular}

